\title{
ON THE NON-NEUTRALITY OF MONEY: EVIDENCE FROM THE 1990s
}

\author{
Petr DUCZYNSKI *
}

\begin{abstract}
:
The paper examines the cross-country relations between nominal money and real output between 1990 and 2000. Both high money growth rates and declines in money are connected with below-average output growth rates. The association between the monetary base and real output is weaker than between M1 (or M2) and real output. I observe no tendency of money changes to precede output changes.
\end{abstract}

Keywords: consumer prices, M1, M2, monetary base, real output

JEL Classification: E32, E51

\section{Introduction}

One of the most important and interesting problems in macroeconomics is whether nominal money has real effects. Most economists believe that money is neutral in the long run but non-neutral in the short run. Friedman and Schwartz (1963) and Romer and Romer (1989) show that money mattered in the United States. Other studies of the non-neutrality of money include Barro (1978), Wogin (1980), Attfield, Demery and Duck (1981), Attfield and Duck (1983) and Kormendi and Meguire (1984).

The present paper's goal is to complement the existing literature by providing evidence from all countries for which there are data in the $1990-2000$ period. The data are taken from the International Financial Statistics Yearbook (2002) of the International Monetary Fund. I exclude observations for which there was a methodological change. The paper focuses on the average behavior of the real output growth in extreme situations - falls in monetary aggregates and high growth rates of money (above $50 \%$ per year). The output growth is found to be low in both of these extreme cases.

One of the research questions addressed in this paper is whether the behavior of output is more adverse for falls in the monetary base, M1, or M2. It was found that the behavior of output is more adverse for falls in $\mathrm{M} 1$ than for falls in the monetary base, and slightly more adverse for falls in M2 than for falls in M1. Hence broader monetary aggregates are more strongly associated with real output than narro-

*) Department of Economics and Management, Faculty of Informatics and Management, University of Hradec Králové, Víta Nejedlého 573, CZ - 50003 Hradec Králové (e-mail: petr.duczynski@ @erge-ei.cz).

$\left.{ }^{\star \star}\right)$ This work was supported by the Grant Agency of the Czech Republic, grant number 402/04/0642. 
wer monetary aggregates. This observation is consistent with my findings in Duczynski (2001a, 2001b), where I examined earlier data.

Another research question is whether there exists a tendency of money changes to precede output changes. Unlike gros domestic product (GDP), the monetary aggregates are measured from end-of-year data. If $T$ is the year in which the monetary variable falls, the output growth in $T$ (between $T$-1 and $T$ ) in some sense precedes the monetary change in $T$ (the growth rate of output is derived from the output behavior both in $T-1$ and $T$ ). Similarly, the output growth in $T+1$ follows the monetary change in $T$. If the output performance between $T$ and $T+1$ were on average more adverse than the output performance between $T$-1 and $T$, it would be an indication that money changes precede output changes. However, this was not observed in the data. In contrast, in Duczynski (2001a, 2001b) I observe some tendency of money changes to precede per capita output changes (I use the Summers-Heston data set for output per capita). Since it is more natural to observe monetary changes to precede output changes (the monetary policy is plausibly effective with a lag), I can speculate that the quality of the Summers-Heston data might be better than the quality of the GDP data of the International Monetary Fund.

In addition, the paper examines the average output performance in the years in which consumer prices declined. The output growth rate is below the long-run crosscountry average in these situations. Thus the price level is procyclical. This observation underscores the importance of demand shocks in business fluctuations.

\section{Channels of Monetary Policy}

Money affects real output through the interest rate channel, the exchange rate channel, the equity channel, the bank lending channel, and the balance sheet channel. A monetary expansion leads to lower interest rates. Lower interest rates stimulate demand for investment goods and consumer durable goods (the interest rate channel). In an open economy with flexible exchange rates, lower interest rates induce capital outflow and the exchange rate depreciation. This leads to higher net exports and higher output (the exchange rate channel). Lower interest rates increase prices of securities. The wealth of households increases, which stimulates consumption (the equity channel). A monetary contraction decreases the supply of credit in an economy. This affects the real economy since many firms do not have easy substitutes for bank loans (the bank lending channel). A monetary contraction also decreases the net worth and cash flows of firms, which exacerbates problems with asymmetric information in credit markets (the balance sheet channel).

\section{Monetary Non-neutrality in Selected Previous Studies}

Friedman and Schwartz (1963) describe the monetary development in the United States in $1867-1960$. The book starts with the greenback period and ends with the postwar rise in the velocity of money. It presents the evolution of money, income, prices, and velocity. Attention is paid to the Great Depression in $1929-1933$. Apart from banking panics, Friedman and Schwartz identify four periods of monetary shocks (January-June 1920, October 1931, June 1936-January 1937, and, in general, the passivity of the Fed in the Depression years $1929-1931$ ) in which the monetary movement was unusual given economic conditions. They document that these monetary shocks were associated with declines in the real economic activity.

Romer and Romer (1989) follow the narrative approach of Friedman and Schwartz. Unlike Friedman and Schwartz, they count as a monetary shock only si- 
tuations in which the Fed attempted to exert a contractionary influence on the real economy in order to reduce inflation. They add shocks in 1933 and 1941 and do not consider the shock in the early stages of the Great Depression. They carry out an analysis for the postwar period with shocks in October 1947, September 1955, December 1968, April 1974, August 1978, and October 1979. They show that these contractionary measures really had significant real effects. The effects of monetary policy were found to be more persistent in the postwar era than in the interwar period. Demand disturbances were observed to be a primary source of postwar economic fluctuations. Romer and Romer acknowledge the difficulty of the implementation of the narrative approach in the interwar period.

A complementary approach is the statistical approach (applied in the present paper). Attfield and Duck (1983) and Kormendi and Meguire (1984) are examples of studies which use the statistical approach. These studies focus on the effects of unanticipated monetary changes. Attfield and Duck examine data from 11 countries. They show that monetary growth effects real output only if it is unpredictable and that the effectiveness of monetary policy decreases with the variance of the money growth. Kormendi and Meguire examine 47 countries, observing a short-run nonneutrality of money and a long-run monetary neutrality. The maximum effect of a monetary shock on real output occurs within a year of the shock. Consistently with the rational expectations hypothesis, Kormendi and Meguire observe that effectiveness of monetary policy decreases with the variance of monetary shocks.

\section{The Results}

\section{Declines in $\mathrm{M1}$}

Table 1

Growth Rates of M1 and Real Output in the Years in which M1 Declined

\begin{tabular}{|l|c|c|c|c|}
\hline Country & Year & $\Delta \mathrm{M} 1 / \mathrm{M} 1(\%)$ & $g(\%)$ & $g+1(\%)$ \\
\hline \multirow{2}{*}{ Industrial countries } & \multicolumn{5}{|l|}{} \\
\cline { 2 - 5 } & 1992 & -0.9 & 0.6 & 0.0 \\
\hline \multirow{2}{*}{ Greece } & 1994 & -1.4 & 5.5 & 2.8 \\
\hline \multirow{3}{*}{ Ireland } & 2000 & -4.0 & 4.1 & 4.1 \\
\cline { 2 - 5 } & 1991 & -1.7 & 1.9 & 3.3 \\
\hline \multirow{2}{*}{ New Zealand } & 1997 & -17.4 & 10.8 & 8.6 \\
\hline \multirow{2}{*}{ Spain } & 1996 & -4.5 & 3.1 & 2.6 \\
\hline \multirow{3}{*}{ Switzerland } & 1992 & -2.0 & 0.7 & -1.2 \\
\cline { 2 - 5 } & 1990 & -1.6 & 3.7 & -0.8 \\
\cline { 2 - 5 } & 1991 & -1.7 & -0.8 & -0.1 \\
\hline \multirow{3}{*}{ United States } & 2000 & -2.1 & 3.0 & 1.3 \\
\cline { 2 - 5 } & 1995 & -0.9 & 2.7 & 3.6 \\
\hline
\end{tabular}




\begin{tabular}{|c|c|c|c|c|}
\hline Country & Year & $\Delta \mathrm{M} 1 / \mathrm{M} 1(\%)$ & $g(\%)$ & $g+1(\%)$ \\
\hline \multicolumn{5}{|c|}{ Developing countries } \\
\hline \multicolumn{5}{|l|}{ Africa } \\
\hline \multirow{3}{*}{ Benin } & 1993 & -13.2 & 3.5 & 4.4 \\
\hline & 1995 & -13.2 & 4.6 & 5.5 \\
\hline & 1998 & -4.7 & 4.5 & 5.0 \\
\hline Botswana & 1992 & -1.1 & 6.2 & -0.2 \\
\hline \multirow[t]{3}{*}{ Burkina Faso } & 1990 & -1.7 & -1.0 & 9.5 \\
\hline & 1998 & -2.6 & 5.5 & 6.4 \\
\hline & 1999 & -1.9 & 6.4 & 2.4 \\
\hline Burundi & 1995 & -3.3 & -7.0 & -8.6 \\
\hline \multirow[t]{5}{*}{ Cameroon } & 1990 & -7.5 & -6.7 & -3.9 \\
\hline & 1992 & -27.6 & -3.0 & -3.2 \\
\hline & 1993 & -14.1 & -3.2 & -2.6 \\
\hline & 1995 & -11.6 & 3.3 & 5.0 \\
\hline & 1996 & -1.6 & 5.0 & 5.0 \\
\hline \multirow[t]{3}{*}{ Congo } & 1991 & -7.3 & 2.4 & 1.7 \\
\hline & 1993 & -19.7 & -1.0 & -5.5 \\
\hline & 1998 & -13.6 & 3.7 & -3.2 \\
\hline \multirow[t]{2}{*}{ Côte d'Ivoire } & 1991 & -3.1 & n.a. & -0.1 \\
\hline & 1992 & -4.0 & -0.1 & -0.4 \\
\hline Gambia & 1994 & -11.7 & 3.6 & -4.1 \\
\hline Guinea-Bissau & 1991 & -74.8 & 3.8 & 1.8 \\
\hline Lesotho & 1999 & -2.6 & 2.0 & 2.5 \\
\hline Madagascar & 1990 & -4.0 & 3.1 & -6.3 \\
\hline \multirow[t]{5}{*}{ Niger } & 1990 & -11.7 & -0.8 & 1.4 \\
\hline & 1992 & -10.5 & 0.7 & 1.0 \\
\hline & 1996 & -9.5 & 3.9 & 2.4 \\
\hline & 1997 & -19.4 & 2.4 & 8.6 \\
\hline & 1998 & -18.5 & 8.6 & n.a. \\
\hline Rwanda & 1998 & -0.8 & 9.2 & 6.1 \\
\hline \multirow[t]{3}{*}{ Senegal } & 1990 & -11.5 & 3.9 & -0.4 \\
\hline & 1993 & -9.0 & -2.2 & 2.9 \\
\hline & 1997 & -0.1 & 5.0 & 5.7 \\
\hline
\end{tabular}




\begin{tabular}{|c|c|c|c|c|}
\hline Country & Year & $\Delta \mathrm{M} 1 / \mathrm{M} 1(\%)$ & $g(\%)$ & $g+1(\%)$ \\
\hline \multirow[t]{2}{*}{ Seychelles } & 1990 & -1.3 & 7.5 & 2.7 \\
\hline & 1994 & -2.7 & -0.8 & -0.6 \\
\hline \multirow[t]{3}{*}{ Togo } & 1992 & -27.2 & -3.8 & -16.6 \\
\hline & 1993 & -18.5 & -16.6 & 16.8 \\
\hline & 1996 & -7.8 & 9.7 & 4.3 \\
\hline \multicolumn{5}{|l|}{ Asia } \\
\hline \multirow[t]{2}{*}{ China, Hong Kong } & 1997 & -3.8 & 5.0 & -5.3 \\
\hline & 1998 & -4.6 & -5.3 & 3.0 \\
\hline Korea & 1997 & -11.4 & 5.0 & -6.7 \\
\hline Laos & 1990 & -0.2 & 6.7 & 4.0 \\
\hline Malaysia & 1998 & -29.4 & -7.4 & 5.8 \\
\hline \multirow[t]{2}{*}{ Papua N. G. } & 1990 & -0.2 & -3.0 & 9.5 \\
\hline & 1997 & -5.5 & -3.9 & -1.1 \\
\hline Philippines & 2000 & -1.3 & 4.0 & 3.4 \\
\hline \multirow[t]{3}{*}{ Samoa } & 1991 & -9.2 & -27.9 & -2.3 \\
\hline & 1992 & -11.4 & -2.3 & 2.4 \\
\hline & 1996 & -0.2 & 6.1 & 1.6 \\
\hline Singapore & 1998 & -1.0 & -0.1 & 6.9 \\
\hline Thailand & 2000 & -7.5 & 4.6 & 1.8 \\
\hline \multirow[t]{2}{*}{ Tonga } & 1992 & -12.7 & -3.8 & -0.1 \\
\hline & 1994 & -5.5 & 4.8 & n.a. \\
\hline Vanuatu & 1990 & -10.9 & 5.2 & 10.4 \\
\hline \multicolumn{5}{|l|}{ Europe } \\
\hline Armenia & 1999 & -0.9 & 3.3 & n.a. \\
\hline Croatia & 1998 & -1.4 & 2.5 & -0.8 \\
\hline Czech Republic & 1998 & -3.4 & -1.0 & 0.5 \\
\hline Estonia & 1998 & -6.3 & 5.0 & -0.7 \\
\hline Lithuania & 1999 & -5.3 & -3.9 & 3.9 \\
\hline Malta & 1996 & -1.9 & 4.0 & 4.9 \\
\hline Poland & 2000 & -6.4 & 4.0 & 1.0 \\
\hline \multirow[t]{2}{*}{ Slovak Republic } & 1997 & -4.4 & 6.2 & 4.1 \\
\hline & 1998 & -11.4 & 4.1 & 1.9 \\
\hline
\end{tabular}




\begin{tabular}{|c|c|c|c|c|}
\hline Country & Year & $\Delta \mathrm{M} 1 / \mathrm{M} 1(\%)$ & $g(\%)$ & $g+1(\%)$ \\
\hline \multicolumn{5}{|l|}{ Middle East } \\
\hline \multirow[t]{2}{*}{ Bahrain } & 1994 & -5.5 & -0.3 & 3.9 \\
\hline & 1995 & -3.6 & 3.9 & 4.1 \\
\hline \multirow[t]{3}{*}{ Jordan } & 1995 & -0.2 & 6.4 & 2.1 \\
\hline & 1996 & -11.8 & 2.1 & 3.1 \\
\hline & 1998 & -0.8 & 2.9 & n.a. \\
\hline \multirow[t]{2}{*}{ Kuwait } & 1992 & -7.7 & -7.3 & 33.8 \\
\hline & 1998 & -8.3 & 3.2 & -1.6 \\
\hline \multirow[t]{2}{*}{ Oman } & 1995 & -0.3 & 4.8 & 2.9 \\
\hline & 1998 & -8.0 & 2.7 & -0.2 \\
\hline \multirow[t]{3}{*}{ Saudi Arabia } & 1993 & -1.6 & -0.6 & 0.5 \\
\hline & 1995 & -0.2 & 0.5 & 1.4 \\
\hline & 1998 & -0.6 & 2.8 & -0.8 \\
\hline $\begin{array}{l}\text { United Arab } \\
\text { Emirates }\end{array}$ & 1990 & -2.7 & 17.5 & 0.8 \\
\hline Yemen & 1996 & -4.5 & 2.9 & 8.1 \\
\hline \multicolumn{5}{|c|}{ Western Hemisphere } \\
\hline \multirow{2}{*}{$\begin{array}{l}\text { Antigua and } \\
\text { Barbuda }\end{array}$} & 1996 & -8.7 & 6.6 & 5.2 \\
\hline & 1999 & -1.3 & 3.7 & n.a. \\
\hline Argentina & 2000 & -9.1 & -0.8 & -4.5 \\
\hline \multirow[t]{4}{*}{ Barbados } & 1991 & -5.9 & -3.9 & -7.2 \\
\hline & 1993 & -5.1 & 0.8 & 4.3 \\
\hline & 1995 & -17.0 & 2.3 & 2.5 \\
\hline & 1997 & -1.1 & 2.9 & 4.4 \\
\hline Bolivia & 1999 & -5.8 & 0.4 & 2.4 \\
\hline Chile & 1998 & -13.3 & 3.2 & -1.0 \\
\hline Colombia & 1998 & -7.8 & 0.6 & -4.2 \\
\hline Costa Rica & 1995 & -6.0 & 3.9 & 0.9 \\
\hline \multirow{4}{*}{$\begin{array}{l}\text { Dominican } \\
\text { Republic }\end{array}$} & 1993 & -12.1 & 1.7 & 1.4 \\
\hline & 1994 & -1.8 & 1.4 & 1.7 \\
\hline & 1997 & -0.3 & 1.9 & n.a. \\
\hline & 2000 & -1.1 & 7.7 & n.a. \\
\hline Ecuador & 1995 & -20.3 & 2.3 & 2.0 \\
\hline
\end{tabular}




\begin{tabular}{|c|c|c|c|c|}
\hline Country & Year & $\Delta \mathrm{M} 1 / \mathrm{M} 1(\%)$ & $g(\%)$ & $g+1(\%)$ \\
\hline \multirow[t]{2}{*}{ EI Salvador } & 1997 & -2.1 & 4.2 & 3.8 \\
\hline & 2000 & -11.7 & -40.4 & 1.8 \\
\hline Grenada & 1991 & -1.7 & 2.9 & 0.6 \\
\hline \multirow[t]{2}{*}{ Haiti } & 1990 & -12.6 & 0.2 & 4.7 \\
\hline & 1996 & -13.1 & 2.7 & 2.7 \\
\hline Nicaragua & 1993 & -4.6 & -0.4 & 3.3 \\
\hline Peru & 2000 & -5.4 & 3.1 & 0.2 \\
\hline \multirow[t]{3}{*}{ St. Kitts and Nevis } & 1990 & -2.0 & 2.3 & 0.4 \\
\hline & 1994 & -4.1 & 5.1 & 3.7 \\
\hline & 1997 & -1.0 & 6.8 & 1.1 \\
\hline St. Lucia & 1996 & -6.9 & 0.8 & 0.5 \\
\hline \multirow{3}{*}{$\begin{array}{l}\text { St. Vincent } \\
\text { and Grenadines }\end{array}$} & 1991 & -17.5 & 1.5 & 5.9 \\
\hline & 1993 & -0.3 & 2.4 & -2.0 \\
\hline & 1995 & -0.1 & 7.6 & 1.4 \\
\hline $\begin{array}{l}\text { Trinidad and } \\
\text { Tobago }\end{array}$ & 1992 & -7.7 & -1.6 & -1.5 \\
\hline Uruguay & 2000 & -3.5 & -1.4 & -3.1 \\
\hline
\end{tabular}

Notes: $g$ denotes the growth rate of real output in the year of the monetary decline, while $g+1$ denotes the growth rate of real output in the subsequent year.

Table 1 presents the observations in which M1 declined and also the growth rate of real output in the given year $g$ and in the subsequent year $g+1$. The growth rates of $\mathrm{M} 1$ are under the code $34 x$ (money) in the International Financial Statistics. The growth rates of real output are under the code $99 \mathrm{bp} x$. The average growth rate of M1 in Table 1 is $-7.17 \%$ (standard deviation $8.86 \%$ ). The average $g$ is $1.57 \%$ (118 observations, standard deviation $6.37 \%$ ). The average $g+1$ is $1.86 \%$ (112 observations, standard deviation $5.21 \%$ ). In comparison, the arithmetic average of the growth rates of output in the world between 1990 and 2000 is $3.62 \%$. Both the average $g$ and the average $g+1$ differ significantly from $3.62 \%$ (the $t$-statistic is 3.50 for $g$ and 3.58 for $g+1$ ). Thus there exists a statistically significant association between $\mathrm{M} 1$ and real output. Since the average for $g+1$ exceeds the average for $g$, there is in some sense no tendency of money changes to precede output changes (although money declines are followed by slow growth of output, they are also preceded by slow output growth).

\section{Declines in the Monetary Base}

The growth of the monetary base is under the code $14 x$ (reserve money) in the International Financial Statistics. There are 242 observations in which the monetary base declined between 1990 and 2000 and for which output data are available. The average growth rate of the monetary base in these situations is $-9.56 \%$ (stan- 
dard deviation $9.67 \%$ ). The average $g$ is $2.54 \%$ (238 observations, standard deviation $5.47 \%$ ). The average $g+1$ is $2.48 \%$ (231 observations, standard deviation $4.27 \%$ ). Both of these averages are significantly below the long-run world average, $3.62 \%$ (the $t$-statistic is 3.05 for $g$ and 4.06 for $g+1$ ). It is of some interest to compare the declines in the monetary base to the declines in M1. Although the average decline in the monetary base $(9.56 \%)$ is larger than the average decline in M1 $(7.17 \%)$, the behavior of output is not so adverse for the monetary base. Thus M1 is more strongly associated with real output than the monetary base.

\section{Declines in $\mathrm{M} 2$}

Table 2

\section{Growth Rates of M2 and Real Output in the Years in which M2 Declined}

\begin{tabular}{|c|c|c|c|c|}
\hline Country & Year & $\Delta \mathrm{M} 2 / \mathrm{M} 2(\%)$ & $g(\%)$ & $g+1(\%)$ \\
\hline \multicolumn{5}{|c|}{ Industrial countries } \\
\hline \multirow[t]{3}{*}{ Denmark } & 1992 & -0.7 & 0.6 & 0.0 \\
\hline & 1994 & -10.0 & 5.5 & 2.8 \\
\hline & 1999 & -0.9 & 2.3 & 3.0 \\
\hline \multirow[t]{2}{*}{ Finland } & 1992 & -1.0 & -3.3 & -1.1 \\
\hline & 1996 & -2.9 & 4.0 & 6.3 \\
\hline \multirow[t]{2}{*}{ France } & 1991 & -4.7 & 1.1 & 1.2 \\
\hline & 1992 & -0.1 & 1.2 & -0.9 \\
\hline Italy & 1997 & -5.8 & 2.0 & 1.8 \\
\hline Japan & 1992 & -0.1 & 0.9 & 0.5 \\
\hline Luxembourg & 1997 & -4.5 & 9.1 & 5.9 \\
\hline Norway & 1993 & -0.7 & 2.7 & 5.5 \\
\hline Sweden & 1998 & -0.4 & 3.6 & 4.5 \\
\hline Switzerland & 2000 & -16.9 & 3.0 & 1.3 \\
\hline \multicolumn{5}{|c|}{ Developing countries } \\
\hline \multicolumn{5}{|l|}{ Africa } \\
\hline \multirow[t]{3}{*}{ Benin } & 1993 & -3.1 & 3.5 & 4.4 \\
\hline & 1995 & -1.8 & 4.6 & 5.5 \\
\hline & 1998 & -3.6 & 4.5 & 5.0 \\
\hline \multirow[t]{2}{*}{ Botswana } & 1990 & -14.0 & 6.4 & 8.8 \\
\hline & 1993 & -14.4 & -0.2 & 4.0 \\
\hline Burkina Faso & 1990 & -0.5 & -1.0 & 9.5 \\
\hline \multirow[t]{2}{*}{ Burundi } & 1995 & -11.2 & -7.0 & -8.6 \\
\hline & 1998 & -3.7 & 4.5 & n.a. \\
\hline
\end{tabular}




\begin{tabular}{|c|c|c|c|c|}
\hline Country & Year & $\Delta \mathrm{M} 2 / \mathrm{M} 2(\%)$ & $g(\%)$ & $g+1(\%)$ \\
\hline \multirow[t]{5}{*}{ Cameroon } & 1990 & -1.7 & -6.7 & -3.9 \\
\hline & 1992 & -21.9 & -3.0 & -3.2 \\
\hline & 1993 & -9.2 & -3.2 & -2.6 \\
\hline & 1995 & -6.2 & 3.3 & 5.0 \\
\hline & 1996 & -10.1 & 5.0 & 5.0 \\
\hline \multirow[t]{4}{*}{ Congo } & 1991 & -4.2 & 2.4 & 1.7 \\
\hline & 1993 & -26.6 & -1.0 & -5.5 \\
\hline & 1995 & -0.1 & 2.2 & 4.3 \\
\hline & 1998 & -12.8 & 3.7 & -3.2 \\
\hline \multirow[t]{3}{*}{ Côte d'Ivoire } & 1990 & -2.6 & -1.1 & n.a. \\
\hline & 1992 & -1.2 & -0.1 & -0.4 \\
\hline & 1993 & -1.4 & -0.4 & 2.0 \\
\hline Gambia & 1994 & -3.8 & 3.6 & -4.1 \\
\hline Guinea-Bissau & 1991 & -67.3 & 3.8 & 1.8 \\
\hline Lesotho & 1999 & -5.1 & 2.0 & 2.5 \\
\hline \multirow[t]{6}{*}{ Niger } & 1990 & -4.1 & -0.8 & 1.4 \\
\hline & 1991 & -8.9 & 1.4 & 0.7 \\
\hline & 1992 & -1.0 & 0.7 & 1.0 \\
\hline & 1996 & -6.6 & 3.9 & 2.4 \\
\hline & 1997 & -21.3 & 2.4 & 8.6 \\
\hline & 1998 & -18.5 & 8.6 & n.a. \\
\hline Rwanda & 1994 & -3.7 & -49.7 & 34.2 \\
\hline \multirow[t]{2}{*}{ Senegal } & 1990 & -4.8 & 3.9 & -0.4 \\
\hline & 1993 & -12.6 & -2.2 & 2.9 \\
\hline Seychelles & 1994 & -0.8 & -0.8 & -0.6 \\
\hline \multirow[t]{3}{*}{ Togo } & 1992 & -18.0 & -3.8 & -16.6 \\
\hline & 1993 & -16.2 & -16.6 & 16.8 \\
\hline & 1996 & -6.3 & 9.7 & 4.3 \\
\hline \multicolumn{5}{|l|}{ Asia } \\
\hline Malaysia & 1998 & -1.4 & -7.4 & 5.8 \\
\hline Mongolia & 1998 & -1.7 & 3.5 & n.a. \\
\hline Papua N. G. & 1994 & -1.3 & 5.9 & -3.3 \\
\hline Samoa & 1991 & -1.9 & -27.9 & -2.3 \\
\hline Singapore & 2000 & -2.0 & 10.3 & -2.0 \\
\hline
\end{tabular}




\begin{tabular}{|c|c|c|c|c|}
\hline Country & Year & $\Delta \mathrm{M} 2 / \mathrm{M} 2(\%)$ & $g(\%)$ & $g+1(\%)$ \\
\hline Tonga & 1992 & -4.8 & -3.8 & -0.1 \\
\hline \multirow[t]{2}{*}{ Vanuatu } & 1991 & -0.7 & 10.4 & -0.7 \\
\hline & 1992 & -2.6 & -0.7 & 4.5 \\
\hline \multicolumn{5}{|l|}{ Europe } \\
\hline Bulgaria & 1993 & -63.3 & -1.5 & 1.8 \\
\hline Croatia & 1999 & -1.8 & -0.8 & 3.7 \\
\hline Latvia & 1995 & -21.4 & -0.8 & 3.3 \\
\hline Lithuania & 1996 & -3.5 & 4.7 & 7.3 \\
\hline \multicolumn{5}{|l|}{ Middle East } \\
\hline Bahrain & 1990 & -11.6 & 4.4 & 11.2 \\
\hline Jordan & 1996 & -0.9 & 2.1 & 3.1 \\
\hline \multirow[t]{2}{*}{ Kuwait } & 1996 & -0.6 & -2.7 & 1.2 \\
\hline & 1998 & -0.8 & 3.2 & -1.6 \\
\hline $\begin{array}{l}\text { United Arab } \\
\text { Emirates }\end{array}$ & 1990 & -8.2 & 17.5 & 0.8 \\
\hline \multicolumn{5}{|c|}{ Western Hemisphere } \\
\hline $\begin{array}{l}\text { Antigua and } \\
\text { Barbuda }\end{array}$ & 1996 & -4.0 & 6.6 & 5.2 \\
\hline Argentina & 1995 & -2.8 & -2.8 & 5.5 \\
\hline Barbados & 1991 & -1.1 & -3.9 & -7.2 \\
\hline $\begin{array}{l}\text { Dominican } \\
\text { Republic }\end{array}$ & 1993 & -2.2 & 1.7 & 1.4 \\
\hline Mexico & 2000 & -5.7 & 6.6 & -0.3 \\
\hline Peru & 2000 & -0.4 & 3.1 & 0.2 \\
\hline $\begin{array}{l}\text { St. Vincent } \\
\text { and Grenadines }\end{array}$ & 1991 & -1.2 & 5.1 & 1.5 \\
\hline $\begin{array}{l}\text { Trinidad and } \\
\text { Tobago }\end{array}$ & 1992 & -6.9 & -1.6 & -1.5 \\
\hline
\end{tabular}

The growth rate of M2 is under the code $351 x$ (money plus quasi money) in the International Financial Statistics. There are 74 observations in which $\mathrm{M} 2$ declined and for which output data are available (see Table 2). The average growth rate of $\mathrm{M} 2$ is $-7.44 \%$ in these situations. The average output growth rate $g$ is $0.63 \%$ (74 observations, standard deviation $8.34 \%$ ). The average $g+1$ is $2.16 \%$ (70 observations, standard deviation $6.12 \%$ ). The average $g$ is significantly below the world long-run average, $3.62 \%$ (the $t$-statistic is 3.08). The average $g+1$ is also significantly below the world average (the $t$-statistic is 2.00). If the declines in M2 are compared to the declines in the monetary base, it follows that the behavior of real output is more adverse for the declines in M2 (both for $g$ and $g+1$ ) despite the fact that 
the average decline in the monetary base $(9.56 \%)$ exceeds the average decline in M2 (7.44 \%). Thus M2 is more strongly associated with real output than the monetary base. We observe only a small difference if the declines in M2 are compared to the declines in M1. The average decline in M2 (7.44\%) only slightly exceeds the average decline in M1 $(7.17 \%)$. The average decline in M2 would be smaller if I excluded the decline of $63.3 \%$ in Bulgaria in 1993. The average of $g$ for the declines in M2 $(0.63 \%)$ is below the average of $g$ for the declines in M1 $(1.57 \%)$. On the other hand, the average of $g+1$ for the declines in M2 $(2.16 \%)$ is above the average of $g+1$ for the declines in M1 (1.86\%). For the declines in M2, the arithmetic average of the averages of $g$ and $g+1$ is $1.40 \%$. For the declines in $\mathrm{M} 1$, the arithmetic average of the averages of $g$ and $g+1$ is $1.72 \%$. Thus, the behavior of output is somewhat more adverse for the declines in $\mathrm{M} 2$ than for the declines in $\mathrm{M} 1$. This is (limited) evidence that M2 is more strongly associated with real output than M1.

\section{High Growth of $M 1$}

Table 3

Growth Rates of M1 and Real Output in the Years in which the Growth of M1 Exceeded $50 \%$

\begin{tabular}{|c|c|c|c|c|}
\hline Country & Year & $\Delta \mathrm{M} 1 / \mathrm{M} 1(\%)$ & $g(\%)$ & $g+1(\%)$ \\
\hline \multicolumn{5}{|c|}{ Developing countries } \\
\hline \multicolumn{5}{|l|}{ Africa } \\
\hline Benin & 1994 & 67.3 & 4.4 & 4.6 \\
\hline \multirow[t]{7}{*}{ Congo } & 1990 & 176.0 & -6.6 & -8.4 \\
\hline & 1991 & $2,387.0$ & -8.4 & -10.5 \\
\hline & 1992 & $4,114.0$ & -10.5 & -13.5 \\
\hline & 1993 & $2,461.0$ & -13.5 & -3.9 \\
\hline & 1994 & $5,635.0$ & -3.9 & 0.7 \\
\hline & 1995 & 407.0 & 0.7 & -0.9 \\
\hline & 2000 & 68.2 & 8.0 & n.a. \\
\hline Côte d'Ivoire & 1994 & 61.7 & 2.0 & 7.1 \\
\hline \multirow[t]{2}{*}{ Ghana } & 1992 & 53.0 & 3.9 & 4.9 \\
\hline & 1994 & 50.3 & 3.3 & 4.0 \\
\hline \multirow[t]{5}{*}{ Guinea-Bissau } & 1990 & 729.2 & 6.1 & 3.8 \\
\hline & 1992 & 83.1 & 1.8 & 2.5 \\
\hline & 1994 & 58.1 & 5.0 & 3.7 \\
\hline & 1996 & 51.0 & 4.8 & 4.8 \\
\hline & 1997 & 236.3 & 4.8 & n.a. \\
\hline Madagascar & 1994 & 56.5 & -0.1 & 1.7 \\
\hline
\end{tabular}




\begin{tabular}{|c|c|c|c|c|}
\hline Country & Year & $\Delta \mathrm{M} 1 / \mathrm{M} 1(\%)$ & $g(\%)$ & $g+1(\%)$ \\
\hline \multirow[t]{2}{*}{ Malawi } & 1994 & 50.5 & -11.6 & 13.8 \\
\hline & 1998 & 56.2 & 2.2 & 3.6 \\
\hline \multirow[t]{2}{*}{ Mozambique } & 1993 & 52.0 & 6.8 & 7.0 \\
\hline & 1994 & 50.5 & 7.0 & 3.3 \\
\hline Namibia & 1996 & 53.6 & 3.2 & 4.2 \\
\hline Nigeria & 1993 & 57.0 & 2.2 & -0.6 \\
\hline Senegal & 1994 & 54.4 & 2.9 & 5.2 \\
\hline \multirow[t]{3}{*}{ Sierra Leone } & 1990 & 64.3 & 3.4 & 2.4 \\
\hline & 1991 & 76.1 & 2.4 & -19.0 \\
\hline & 1997 & 57.1 & -17.6 & -0.9 \\
\hline Togo & 1994 & 104.6 & 16.8 & 6.9 \\
\hline \multirow[t]{3}{*}{ Zambia } & 1990 & 60.6 & -0.5 & n.a. \\
\hline & 1991 & 77.5 & n.a. & -1.7 \\
\hline & 1995 & 61.1 & -2.3 & 6.5 \\
\hline \multirow[t]{3}{*}{ Zimbabwe } & 1993 & 94.9 & 1.3 & 6.8 \\
\hline & 1995 & 52.4 & -0.7 & 7.6 \\
\hline & 1997 & 53.7 & 4.3 & n.a. \\
\hline \multicolumn{5}{|l|}{ Asia } \\
\hline \multirow[t]{2}{*}{ Laos } & 1998 & 111.4 & 4.0 & 7.3 \\
\hline & 2000 & 57.3 & 5.7 & n.a. \\
\hline \multirow[t]{2}{*}{ Mongolia } & 1993 & 142.8 & -3.0 & 2.3 \\
\hline & 1994 & 78.2 & 2.3 & 6.3 \\
\hline Papua N. G. & 1996 & 52.0 & 7.7 & -3.9 \\
\hline Thailand & 1999 & 64.0 & 4.4 & 4.6 \\
\hline \multicolumn{5}{|l|}{ Europe } \\
\hline \multirow[t]{2}{*}{ Armenia } & 1994 & 907.3 & n.a. & 6.9 \\
\hline & 1995 & 124.3 & 6.9 & 5.9 \\
\hline \multirow[t]{5}{*}{ Belarus } & 1995 & 273.2 & -10.4 & 2.8 \\
\hline & 1997 & 115.5 & 11.4 & 8.4 \\
\hline & 1998 & 139.1 & 8.4 & 3.4 \\
\hline & 1999 & 188.4 & 3.4 & 5.8 \\
\hline & 2000 & 117.8 & 5.8 & 4.1 \\
\hline Bulgaria & 1996 & 115.7 & -10.1 & -6.9 \\
\hline Croatia & 1994 & 112.2 & 5.8 & 6.8 \\
\hline
\end{tabular}




\begin{tabular}{|c|c|c|c|c|}
\hline Country & Year & $\Delta \mathrm{M} 1 / \mathrm{M} 1(\%)$ & $g(\%)$ & $g+1(\%)$ \\
\hline Czech Republic & 1994 & 50.2 & 2.2 & 5.9 \\
\hline Poland & 1990 & 401.1 & -11.4 & -7.0 \\
\hline \multirow[t]{7}{*}{ Romania } & 1991 & 214.3 & -13.1 & -8.7 \\
\hline & 1993 & 95.0 & 1.5 & 3.9 \\
\hline & 1994 & 107.8 & 3.9 & 7.1 \\
\hline & 1995 & 57.7 & 7.1 & 3.9 \\
\hline & 1996 & 58.7 & 3.9 & -6.1 \\
\hline & 1997 & 66.9 & -6.1 & -4.8 \\
\hline & 2000 & 55.9 & 1.8 & 5.3 \\
\hline Slovenia & 1992 & 133.7 & -5.5 & 2.8 \\
\hline \multirow[t]{10}{*}{ Turkey } & 1990 & 58.4 & 9.3 & 0.9 \\
\hline & 1992 & 72.5 & 6.0 & 8.0 \\
\hline & 1993 & 64.8 & 8.0 & -5.5 \\
\hline & 1994 & 81.5 & -5.5 & 7.2 \\
\hline & 1995 & 68.3 & 7.2 & 7.0 \\
\hline & 1996 & 129.5 & 7.0 & 7.5 \\
\hline & 1997 & 69.1 & 7.5 & 3.1 \\
\hline & 1998 & 63.1 & 3.1 & -4.7 \\
\hline & 1999 & 77.0 & -4.7 & 7.2 \\
\hline & 2000 & 53.5 & 7.2 & n.a. \\
\hline \multicolumn{5}{|c|}{ Western Hemisphere } \\
\hline Argentina & 1991 & 148.6 & 10.6 & 9.6 \\
\hline \multirow[t]{5}{*}{ Brazil } & 1990 & $2,333.6$ & 0.4 & 1.0 \\
\hline & 1991 & 429.4 & 1.0 & -0.5 \\
\hline & 1992 & 981.8 & -0.5 & 4.9 \\
\hline & 1993 & $2,017.8$ & 4.9 & 5.8 \\
\hline & 1994 & $2,195.4$ & 5.8 & 4.2 \\
\hline \multirow[t]{2}{*}{ Guyana } & 1990 & 54.5 & -4.7 & 6.0 \\
\hline & 1991 & 65.5 & 6.0 & 7.8 \\
\hline \multirow[t]{2}{*}{ Jamaica } & 1991 & 94.7 & 0.8 & 1.7 \\
\hline & 1992 & 71.3 & 1.7 & 2.0 \\
\hline \multirow[t]{2}{*}{ Mexico } & 1990 & 63.1 & 5.1 & 4.2 \\
\hline & 1991 & 123.9 & 4.2 & 3.6 \\
\hline
\end{tabular}




\begin{tabular}{|l|c|c|c|c|}
\hline Country & Year & $\Delta \mathrm{M} 1 / \mathrm{M} 1(\%)$ & $g(\%)$ & $g+1(\%)$ \\
\hline \multirow{3}{*}{ Nicaragua } & 1990 & $6,286.7$ & -0.1 & -0.2 \\
\cline { 2 - 5 } & 1991 & $1,336.9$ & -0.2 & 0.4 \\
\cline { 2 - 5 } & 1990 & $6,724.8$ & -3.7 & 2.2 \\
\cline { 2 - 5 } & 1991 & 127.2 & 2.2 & -0.4 \\
\cline { 2 - 5 } & 1992 & 76.9 & -0.4 & 4.8 \\
\cline { 2 - 5 } & 1993 & 52.6 & 4.8 & 12.8 \\
\hline \multirow{4}{*}{ Suriname } & 1997 & 69.1 & 6.7 & -0.5 \\
\cline { 2 - 5 } & 1993 & 87.6 & -4.5 & -0.8 \\
\hline \multirow{3}{*}{ Uruguay } & 1994 & 245.6 & -0.8 & $\mathrm{n} . \mathrm{a}$. \\
\cline { 2 - 5 } & 1990 & 96.2 & 0.3 & 3.5 \\
\cline { 2 - 5 } & 1991 & 96.5 & 3.5 & 7.9 \\
\cline { 2 - 5 } & 1992 & 71.2 & 7.9 & 2.7 \\
\hline \multirow{4}{*}{ Venezuela } & 1993 & 57.9 & 2.7 & 7.3 \\
\hline & 1991 & 52.5 & 9.7 & 6.1 \\
\hline & 1994 & 139.2 & -2.3 & 4.0 \\
\hline & 1997 & 77.0 & 6.4 & 0.2 \\
\hline
\end{tabular}

This section considers situations in which M1 grew at a higher rate than $50 \%$ per year (see Table 3). The average $g$ is $1.69 \%$ (standard deviation $6.08 \%$, 95 observations). This is significantly below the world average of $3.62 \%$ (the $t$-statistic is 3.09). The average of $g+1$ is $2.59 \%$ (standard deviation $5.44 \%, 90$ observations). This is marginally significantly below $3.62 \%$ (the $t$-statistic is 1.80). Thus the rapid growth of money is connected with slow growth of output.

\section{Declines in Consumer Prices}

The growth of consumer prices is under the code $64 x$ in the International Financial Statistics. For declines in consumer prices, the average growth rate of output is $2.65 \%$ (standard deviation $5.34 \%, 57$ observations). This average is lower than the world long-run average $3.62 \%$. However, the given difference is statistically insignificant (the $t$-statistic is 1.37). This is limited evidence that the price level is procyclical.

\section{Conclusion}

This paper studies the association between nominal monetary aggregates and real output in extreme situations between 1990 and 2000 in a large number of countries. The output growth performance is below average both for high money growth rates and for declines in money. The association between the monetary base and real output is weaker than the association between $\mathrm{M} 1$ (or M2) and real output. For declines in money in $T$, the growth rate of output between $T$ and $T+1$ (following the 
decline in money) is not lower than the growth rate of output between $T-1$ and $T$ (preceding the decline in money). In this sense there is no tendency of money changes to precede output changes. In addition, the paper provides (limited) evidence that the price level is procyclical (declines in consumer prices are connected with a below-average output growth performance). This observation stresses the importance of demand shocks in business fluctuations.

References

Attfield, C. L. F., Demery, D., Duck, N. W. (1981), "A Quarterly Model of Unanticipated Monetary Growth, Output, and the Price Level in the U.K. 1963-1978." Journal of Monetary Economics, 8 (3), pp. 331-350.

Attfield, C. L. F., Duck, N. W. (1983), "The Influence of Unanticipated Money Growth on Real Output." Journal of Money, Credit, and Banking, 15 (4), pp. 442-454.

Barro, R. J. (1978), "Unanticipated Money, Output, and the Price Level in the United States." Journal of Political Economy, 86 (4), pp. 549-580.

Duczynski, P. (2001), "On the Empirics of the Non-neutrality of Money: Cross-Country Evidence." Florence, European University Institute, Manuscript (a).

(2001), "On the Empirics of the Non-neutrality of Money: Evidence from Developed

Countries." Florence, European University Institute, Manuscript (b).

Friedman, M., Schwartz, A. J. (1963), A Monetary History of the United States, 1867-1960. Princeton: Princeton University Press.

IMF (2002), International Financial Statistics Yearbook. Washington, DC.: International Monetary Fund.

Kormendi, R. C., Meguire, P. G. (1984), "Cross-Regime Evidence of Macroeconomic Rationality." Journal of Political Economy, 92 (5), pp. 875-908.

Romer, C. D., Romer, D. H. (1989), "Does Monetary Policy Matter? A New Test in the Spirit of Friedman and Schwartz." NBER Macroeconomics Annual, pp. 121-170.

Wogin, G. (1980), "Unemployment and Monetary Policy Under Rational Expectations: Some Canadian Evidence." Journal of Monetary Economics, 6 (1), pp. 59-68. 